\title{
Applying and Extending UTAUT2 Model of Adoption of New Technology in the Context of M-Shopping Fashion Apps
}

\author{
Dr. Sunayna Khurana, Dipti Jain
}

\begin{abstract}
The drive of this work is to recognize the factors that affect the adoption of m-shopping fashion apps from the consumer perspective in Delhi NCR by extending UTAUT2 model with Post-purchase behavior with the aim to find out the consumers experience and satisfaction level after adopting new technology (in this case mobile shopping application for fashion).The variables identified including new variable, i.e. perceived risk and post-purchase behaviour, were tested using structural equational modelling. Data collection was done using the structured onlinesurvey on the sample of 557 mobile app users in Delhi-NCR on the young Indian mobile users of age bracket (18-25) years. Theoutcomes of the work revealed that except effort expectancy and social influence, all the remaining factors used in the proposed model significantly influence theformation of behavioral intention of young mobile usersto embrace mobile based fashion shopping apps. Also, the results of the work revealed that consumers actual purchase significantly affect their post-purchase behaviour. Hence, validates the proposed model extended till post adoption.This is the first work in Delhi NCR on the specific mobile shopping application category particularly fashion apps using extended UTAUT2 model.
\end{abstract}

Keywords- Mobile Fashion Applications, Mobile Shopping, Utaut2, Technology Adoption, India

\section{INTRODUCTION}

Mobile phones have come a long way from a device capable of only making and receiving calls and text messages. We can safely say that with the advent of 'Blackberry phones' came the first generation of smart phones with capability for internet services (like checking emails) on the go. Probably the true revolution started after the launch of 'Appstore' in 2008 by Apple (for iPhone) and thereby starting the age of 'mobile applications' or as commonly referred to as just 'apps'.

With the rise in the smart phone ownership, cheap internet data plans, a low learning curve and the demography of young Indian mobile users, the mobile internet user base (smart phone and tablet PCs) is expected to grow by approximately $200 \%$ from 242.92 million in year 2015 to 486.70 million by 2022 , in just seven years[48].Indian $\mathrm{m}$-commerce sales valuing approximately US\$ 6.07 billion in

Revised Manuscript Received on June 15, 2019.

Dr. Sunayna Khurana,MBA, Chandigarh Business School of Administration, Mohali, India.

Ms. Dipti Jain, Management,I.K Gujral Punjab Technical University, Jalandhar, India
2015 and is expected to rise to the US $\$ 37.96$ billion by 2020 (approximately $600 \%$ growth in 5 years). Mobile apps are now ubiquitous and all powerful and many advantages over physical store namely, 24*7 accesses, shopping from anywhere, additional discounts etc. Despite various advantages of retail e-commerce, like infrastructure cost savings, in 2019, they have comparatively very small share of $4.8 \%$ in the total retail sales in India [52]. Though these figures are very good for the new entrants in industry as $95 \%$ of total retail sales is not driven by internet and its allied services highlights the scope of further expansion and growth can be attained via better consumer understanding and subsequent changes to make mobile shopping experience better.

Basis, the above two data points we can infer that the $\mathrm{m}$-shopping is in the nascent stage of expected multi fold growth, but still have not received widespread acceptance in Delhi-NCR.As m-shopping is a new technological trend [6], literature on the drivers of $\mathrm{m}$-shopping fashion app, is scarce, particularly in the subject of fashion [33].

Along with the adoption of fashion apps, the work on post purchase behaviour of consumers is of prime importance for the long-term survival, revenues of fashion apps. $25 \%$ of mobile app on one occasion downloaded is not used after installation [31], which leads to increased costs and losses to app developers [46]. In this way, there is a need to move the focal point of researchers from doing research on adoption phase to post adoption phase [29]. Therefore, identifying and analysing of factors which are hindering m-shopping fashion app adoption as well as post-purchase behaviour of consumers after purchasing fashion products for long term survival of m-shopping fashion apps will be justifiable.

\section{LITERATURE REVIEW}

\section{A.M-shopping Fashion Apps}

Mobile users can have access on online content via two platforms, namely, web browser (websites) and mobile applications downloaded from app stores [53]. Mobile applications are the software which helps mobile users to undertake various day to day activities through mobile devices [37]. The advantages of mobile apps over websites are many like they can work without the internet; they can send push notifications [12]. The scope of this work is limited to shopping related to fashion good which include clothing, footwear and accessories. The term m-shopping fashion app will be frequently used in this

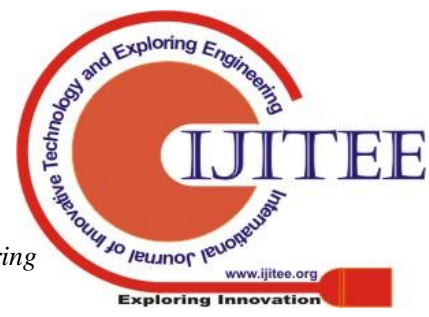


work-shopping fashion apps can be defined as the applications which can be downloaded and installed through operating App stores and allows mobile users to explore, search and buy fashion products through the internet enabled smart phone devices[30].

\section{B. Technology acceptance of Mobile shopping, M-commerce and mobile application}

The Table 1 displays the previous studies conducting in the area of m-commerce, mobile applications, mobile shopping.

\begin{tabular}{|c|c|c|c|}
\hline Author(s) & Context & Variables used & $\begin{array}{l}\text { Outcome } \\
\text { variables }\end{array}$ \\
\hline $\begin{array}{l}\text { K. Madan } \\
\text { and R. } \\
\text { Yadav } \\
{[27]}\end{array}$ & $\begin{array}{l}\text { Mobile } \\
\text { shopping }\end{array}$ & $\begin{array}{l}\text { Hedonic } \\
\text { motivation, } \\
\text { Perceived risk, } \\
\text { facilitating } \\
\text { condition, } \\
\text { Perceived benefits, } \\
\text { Cost, Perceived } \\
\text { Innovativeness, } \\
\text { Perceived } \\
\text { Regulatory Support }\end{array}$ & $\begin{array}{l}\text { Behavioral } \\
\text { intention } \\
\text { and Actual } \\
\text { Adoption } \\
\text { of mobile } \\
\text { shopping }\end{array}$ \\
\hline $\begin{array}{l}\text { H.R. } \\
\text { Marriott } \\
\text { and M.D. } \\
\text { Williams } \\
{[17]}\end{array}$ & $\begin{array}{l}\text { Mobile } \\
\text { shopping }\end{array}$ & $\begin{array}{l}\text { Performance } \\
\text { expectancy, Effort } \\
\text { Expectancy, social } \\
\text { influence, hedonic } \\
\text { motivation, habit, } \\
\text { facilitating } \\
\text { condition, price } \\
\text { value, } \\
\text { innovativeness, } \\
\text { trust and perceived } \\
\text { risk }\end{array}$ & $\begin{array}{l}\text { M-shoppin } \\
\mathrm{g} \text { adoption } \\
\text { behavioral } \\
\text { intention }\end{array}$ \\
\hline $\begin{array}{l}\text { P.K. } \\
\text { Chopdar et } \\
\text { al. [39] }\end{array}$ & $\begin{array}{l}\text { Mobile } \\
\text { shopping } \\
\text { Apps }\end{array}$ & $\begin{array}{l}\text { Performance } \\
\text { expectancy, effort } \\
\text { expectancy, social } \\
\text { influence, } \\
\text { facilitating } \\
\text { conditions, hedonic } \\
\text { motivation, price } \\
\text { value, habit, risk. }\end{array}$ & $\begin{array}{l}\text { Behavioral } \\
\text { intention } \\
\text { and use } \\
\text { behaviour }\end{array}$ \\
\hline $\begin{array}{l}\text { Preeti Tak } \\
\text { and } \\
\text { S.Panwar } \\
\text { [41] }\end{array}$ & $\begin{array}{l}\text { Mobile } \\
\text { Shopping } \\
\text { Apps }\end{array}$ & $\begin{array}{l}\text { performance } \\
\text { expectancy, effort } \\
\text { expectancy, } \\
\text { hedonic motivation, } \\
\text { facilitating } \\
\text { condition social } \\
\text { influence, Price } \\
\text { value, Habit and } \\
\text { deal proneness }\end{array}$ & $\begin{array}{l}\text { Behavioral } \\
\text { intention } \\
\text { and use } \\
\text { behaviour }\end{array}$ \\
\hline $\begin{array}{l}\text { J.J.Hewet } \\
\text { al. [22] }\end{array}$ & $\begin{array}{l}\text { Mobile } \\
\text { Apps }\end{array}$ & $\begin{array}{l}\text { Performance } \\
\text { Expectancy, Effort } \\
\text { Expectancy, } \\
\text { Facilitating } \\
\text { Conditions, } \\
\text { Hedonic }\end{array}$ & $\begin{array}{l}\text { Behavioral } \\
\text { Intention } \\
\text { to use } \\
\text { Mobile } \\
\text { apps. }\end{array}$ \\
\hline
\end{tabular}

\begin{tabular}{|c|c|c|c|}
\hline & & $\begin{array}{l}\text { Motivation, Habit, } \\
\text { Price Value and } \\
\text { Social Influence }\end{array}$ & \\
\hline $\begin{array}{ll}\text { M. } & \text { Groß } \\
{[36]} & \end{array}$ & $\begin{array}{l}\text { Mobile } \\
\text { Shopping }\end{array}$ & $\begin{array}{l}\text { Perceived } \\
\text { Usefulness, } \\
\text { Perceived Ease of } \\
\text { use, Perceived } \\
\text { Enjoyment }\end{array}$ & $\begin{array}{l}\text { Attitude } \\
\text { toward } \\
\text { mobile } \\
\text { Shopping, } \\
\text { Behavioral } \\
\text { Intention } \\
\text { and Use } \\
\text { Behavior }\end{array}$ \\
\hline $\begin{array}{l}\text { M. Hassan } \\
\text { et al. } \\
{[34]}\end{array}$ & $\begin{array}{l}\text { Mobile } \\
\text { Apps }\end{array}$ & $\begin{array}{l}\text { Perceived } \\
\text { usefulness, } \\
\text { perceived ease of } \\
\text { use, perceived } \\
\text { enjoyment, social } \\
\text { needs }\end{array}$ & $\begin{array}{l}\text { Intention } \\
\text { to adopt } \\
\text { apps }\end{array}$ \\
\hline $\begin{array}{l}\text { H.Y. } \\
\text { Wang et } \\
\text { al. [18] }\end{array}$ & $\begin{array}{l}\text { Mobile } \\
\text { Apps }\end{array}$ & $\begin{array}{l}\text { Functional value, } \\
\text { Social value, } \\
\text { Emotional value, } \\
\text { Epistemic value }\end{array}$ & $\begin{array}{l}\text { Behavioral } \\
\text { Intention }\end{array}$ \\
\hline $\begin{array}{l}\text { K.Yang } \\
{[25]}\end{array}$ & $\begin{array}{l}\text { M-Shopp } \\
\text { ing } \\
\text { Adoption }\end{array}$ & $\begin{array}{l}\text { Perceived } \\
\text { usefulness, } \\
\text { perceived } \\
\text { enjoyment, attitude } \\
\text { towards mobile } \\
\text { shopping, } \\
\text { subjective norm and } \\
\text { perceived } \\
\text { behavioral control }\end{array}$ & $\begin{array}{l}\text { Attitude } \\
\text { and } \\
\text { behavioral } \\
\text { intention to } \\
\text { adopt } \\
\text { mobile } \\
\text { shopping }\end{array}$ \\
\hline
\end{tabular}

\section{Table 1: Literature Review}

\section{Utaut2}

The UTAUT framework had been constructed on the basis of earlier eight models and it had pointed 4 factors, particularly, Performance Expectancy, Effort Expectancy, Social Influence and Facilitating condition arousing effect on the formation of behavioural intention and actual use of emerging technology. Therefore [53] expanded their UTAUT model to UTAUT2 by summating three new factors from the consumers' perspective. The constructs added were Price Value, Hedonic Motivation, and Habit. Though, UTAUT and UTAUT2 framework are confined to its own boundaries. Their greatest constraint is not to include perceived risk as a construct to adopt new information technology. In spite of noteworthy predictive power of UTAUT2, there is scarcity of research in the context of mobile shopping fashion application. Hence, in this work the existing model of UTAUT2 will be extended by adding new variable namely perceived risk as an antecedent of behavioural intention to adopt m-shopping fashion apps and adding post -purchase behaviour to find out consumers experience, satisfaction level after purchasing and receiving fashion goods from m-shopping fashion apps

\section{THEORETICAL FRAMEWORK}




\section{A. Performance expectancy}

"Performance expectancy is defined as the degree to which using a technology will provide benefits to consumers in performing certain activities" [53] and for this work can be described as mobile users insight that using m-shopping fashion apps will be advantageous in completing their day to day activities like doing shopping of fashion products anywhere, anytime [30]. PE as confirmed by previous researches is the prime factor which makes a difference on the adoption of mobile shopping in general, mobile internet, mobile application and $\mathrm{m}$-commerce [26,41,39,2,24,14]. Therefore, it is proposed as:

H1: Performance Expectancy is positively associated with the formation of behavioural intention of young mobile users to adopt mobile based fashion shopping apps.

\section{B. Effort expectancy}

Effort expectancy describes that the m-shopping fashion app user didn't find it difficult to use fashion apps for shopping. As mobile apps are designed for use on a touchscreen device, thus users are more comfortable in using them [37,50].The research work of [22] affirmed that adoption of technology is directly proportion to its ease of use. Therefore, it is proposed as:

H2: Effort Expectancy is positively associated with the formation of behavioural intention of young mobile users to adopt mobile based fashion shopping apps.

\section{C.Social influence}

"Social influence is the degree to which an individual perceives that importantothers believe he/she should use the system "[53]. Earlier researches have recognized social influence as a significant factor influencing behavioural intentions to adoption of new technologies like online shopping, mobile payments, mobile app shopping, social media and m-commerce services $[52,25,4120]$. Hence, the succeeding hypothesis has been proposed:

H3: Social Influence is positively associated with the formation of behavioural intention of young mobile users to adopt mobile based fashion shopping apps.

\section{D.Facilitating condition}

Facilitating conditions is an individual perception regarding having access of essential resources required to enable any service [21]. Earlier researches have already recognized facilitating condition as a significant factor influencing behavioural intentions to adopt emerging technologies like mobile shopping, mobile commerce, mobile shopping and tourism [25, 2, 41, 15]. Therefore, it is proposed as:

H4: Facilitating condition is positively associated with the formation of behavioural intention of young mobile users to adopt mobile based fashion shopping apps.

\section{E. Hedonic motivation}

Hedonic motivation is "theenjoy or delight got from utilizing new technology". In this work, it is fun resulting from the use of mobile shopping fashion apps. Hedonic Motivation is set as a noteworthy construct of continuous intention to utilizing an innovation [53]. The studies on mobile sites [51] and We Chat in China [5], have affirmed hedonic motivation to acts as a significant indicator of the formation of behavioral intention. Therefore, it is proposed as:

H5: Hedonic Motivation is positively associated with the formation of behavioural intention of young mobile users to adopt mobile based fashion shopping apps

\section{F.Price value}

"Price value as consumers' cognitive trade -off between the perceived benefits of the applications and the monetary cost for using them" [53]. The cost involved on the part of the consumer though it is quite low. The software i.e. application is free to download; mobile device and internet packs are not purchased only for fashion shopping. The college students are increasingly touchy to cost when contrasted with different users [1]. Therefore, it is proposed as:

H6: Price value is positively associated with the formation of behavioural intention of young mobile users to adopt mobile based fashion shopping apps.

\section{G. Habit}

"Habit has been defined as the extent to which people tend to perform behaviors automatically because of learning [35], while [45] equate habit with In this investigation, Habit is utilized automaticity [53].Habit is to know the tendencies to use m-shopping fashion app in day by day life automatically [20].The result of the work led by [47] established that adoption of technology is in direct proportion to habit Furthermore, studies conducted by on mobile payment [28] and on classroom technology [3] has established a constructive relationship amongst the formation of behavioral intention and habit to use emerging technology. Therefore, it is proposed as:

H7: Habit is positively associated with the formation of behavioural intention of mobile users to adopt mobile based fashion shopping apps.

\section{H.Perceived risk}

Perceived Risk creates interference in the purchase behaviour as it involves losses connected with purchase [40, 65]. Mobile users are subject higher privacy and security risk as users have to log in their personal information while buying products from mobile fashion applications [2, 27]. Many earlier researchers observed a significant and negative relationship between perceived risk and behavioral intention to adopt mobile shopping and thereby interrupting the regular use of mobile shopping $[9,29,39]$. Therefore, it is proposed as:

H8: There is a negative association between perceived risk and formation of behavioural intention to adopt m-shopping apps.

\section{Behavioral intention and use behavior}

In UTAUT Model, Behavioral intention is the prime predecessor of use behavior of an individual to use new technology. Behavioral Intention is determined from the framework of TRA and is characterized as" a proportion of individual strength of intention to undertake predetermined behavior in future [13]. A few examinations in the past have affirmed the strong relationship between behavioural intention and 
use behaviour $[10,23,36,38]$. Hence the following hypothesis has been proposed:

H9: There is a significant positive influence of formedbehavioral intention of young mobile userson actual purchase behavior.

\section{J. Post purchase behaviour}

As the name implies, post purchase is the next stage after purchase. This stage is to measure the difference in prior expectation to actual experience of the service performance of consumer/customer with respect to the service availed. A customer is considered satisfied when their expectations are met or exceeded whereas when expectations are not met the customer is likely to be dissatisfied. A satisfied customer may become loyal and again purchase, as well may recommend to their family and friends [43].

H10: Consumers' actual purchase behavior significantly influences consumers' post - purchase behavior towards m-shopping fashion apps.

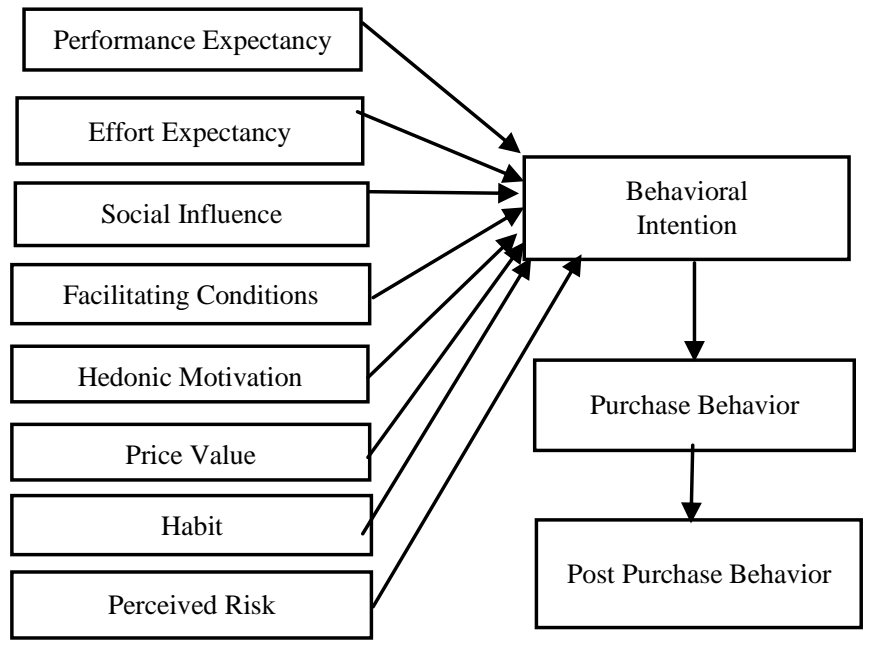

Figure 1: Research Model

\section{RESEARCH METHODOLOGY}

\section{A. Participants}

The selected population for this work is all the young students of Delhi- NCR between the age group of 18-25 years who have the internet enabled mobile phone and have downloaded and used fashion app at least once in a year. Even earlier researches had chosen experienced young student, mobile users for their research work [7,22] stating, experienced users could give better bits of knowledge on what factors motivates them to use or not to use m-shopping fashion apps.

\section{B. Sampling}

Since the list of population (sampling frame) using m-shopping fashion app users in Delhi- NCR was not available, non-probability (convenience, judgemental and snowball) sampling technique is used. Non-Probability sampling techniques were used by earlier researchers to find the adoption of new technology [22, 49].

\section{Instrument Development}

In this work online structured questionnaire is developed on the basis of previous studies. The questionnaire was segregated into four distinct sections. The initial first part was designed to collect data relating to demography of young mobile users, duration and period of using m-shopping fashion apps. The second part consists of factors affecting behavioural intention to use m-shopping fashion apps.with the help of 31 statements related to 8 independent variables. The third and fourth sections measure behavioural Intention and Use Behavior of students with 5 items for checking behavioural intention and 4 items to check Use Behavior. All the items in the questionnaire of section 2,3 and 4 are ascertained by means of 5-point Likert Scale valued from 1-5 where "strongly disagree" was valued at 1 and "Strongly Agree" was valued at 5 .

More evidently, all the items of 7 independent variables (PE, EE, SI, FI, HM, PV, HA) were expropriated from the work of [53] except Perceived Risk. All the items of Perceived Risk were adopted from [29, 39].Also, the items of dependent variables behavioural intention were expropriated from [53] and use behaviour items were expropriated from [36, 39].

\section{Data Collection}

In view to find the weakness in the questionnaire (if applicable), pilot work was conducted with 50 students in January 2015. The results revealed that the statements used in the questionnaire are clear and hence no rephrasing was done. Also, the Cronbach alpha values of the independent variables were above the acceptable range of 0.7 . Hence, no item was dropped. Hyperlink created for the survey via google forms were provided to students and they were requested to forward it to their social groups.

\section{E. Demographic profile}

\begin{tabular}{|c|c|c|}
\hline $\begin{array}{c}\text { Sample } \\
\text { Characteristics }\end{array}$ & $\begin{array}{l}\text { Frequency } \\
(\mathrm{N}=\mathbf{5 5 7})\end{array}$ & $\begin{array}{c}\text { Percentage } \\
(\%)\end{array}$ \\
\hline \multicolumn{3}{|l|}{ Location } \\
\hline Delhi & 314 & 56.4 \\
\hline Faridabad & 114 & 20.5 \\
\hline Ghaziabad & 12 & 2.2 \\
\hline Gurgaon & 53 & 9.5 \\
\hline Sonipat & 64 & 11.5 \\
\hline \multicolumn{3}{|l|}{ Gender } \\
\hline Female & 281 & 50.4 \\
\hline Male & 276 & 49.6 \\
\hline \multicolumn{3}{|l|}{ Age } \\
\hline $18-20$ & 280 & 50.3 \\
\hline $21-23$ & 135 & 24.2 \\
\hline $24-25$ & 142 & 25.5 \\
\hline \multicolumn{3}{|l|}{ Education } \\
\hline
\end{tabular}




\begin{tabular}{|l|l|l|}
\hline Graduate & 113 & 20.3 \\
\hline Others & 16 & 2.9 \\
\hline Post Graduate & 115 & 20.6 \\
\hline $\begin{array}{l}\text { Under } \\
\text { Graduate }\end{array}$ & 313 & 56.2 \\
\hline How often do you use m-shopping fashion apps \\
\hline Daily & 23 & 4.4 \\
\hline Fortnightly & 35 & 6.3 \\
\hline Monthly & 230 & 43.7 \\
\hline Never & 0 & 0 \\
\hline $\begin{array}{l}\text { Once in } 6 \\
\text { months }\end{array}$ & 113 & 20.3 \\
\hline Weekly & 125 & 22.4 \\
\hline Yearly & 31 & 5.6 \\
\hline
\end{tabular}

Table 2: Demographics characteristics

Also, the questionnaire was distributed face to face in the classrooms of Chanderprabhu Jain College of Higher Studies and School of Law, GGSIPU, Delhi. In totality, 672 responses were received and only 557 respondents' responses were used for hypothesis testing.

It is clearly evident from Table 2 that majority of the young mobile users were from the age group of 18-20 years and there is not much difference in the count of males and females. All of them have used mobile apps and have the experience of less than 3 years with using fashion mobile app. The majority of young mobile users use more than one app for purchasing fashion products.

\section{DATA ANALYSIS AND RESULTS}

Hypothesis testing will be done by using SPSS AMOS -STRUCTURAL EQUATIONAL MODELLING (SEM) technique. Reliability and validity related to measurement model will be checked using Confirmatory factor analysis (CFA). The model fit indices and significant $\mathrm{p}$ - value of the items will be observed from the structural model.

\section{A. Reliability and Validity}

The Table 3 shows reliability and validity of the constructs.

\begin{tabular}{|l|l|l|l|l|}
\hline \multicolumn{1}{|c|}{ Factors } & Alpha & CR & AVE & MSV \\
\hline $\begin{array}{l}\text { Perceived } \\
\text { risk(PR) }\end{array}$ & 0.941 & 0.941 & 0.761 & 0.180 \\
\hline $\begin{array}{l}\text { Performance } \\
\text { expectancy(PE) }\end{array}$ & 0.831 & 0.794 & 0.562 & 0.302 \\
\hline $\begin{array}{l}\text { Effort } \\
\text { expectancy(EE) }\end{array}$ & 0.837 & 0.839 & 0.566 & 0.110 \\
\hline Social & 0.878 & 0.880 & 0.649 & 0.180 \\
\hline
\end{tabular}

\begin{tabular}{|l|l|l|l|l|}
\hline influence(SI) & & & & \\
\hline $\begin{array}{l}\text { Hedonic } \\
\text { motivation(HM) }\end{array}$ & 0.925 & 0.926 & 0.758 & 0.388 \\
\hline Habit(HA) & 0.934 & 0.934 & 0.780 & 0.460 \\
\hline Price value(PV) & 0.889 & 0.891 & 0.731 & 0.340 \\
\hline $\begin{array}{l}\text { Facilitating } \\
\text { conditions(FI) }\end{array}$ & 0.838 & 0.841 & 0.640 & 0.144 \\
\hline $\begin{array}{l}\text { Behavioral } \\
\text { intention(BI) }\end{array}$ & 0.901 & 0.901 & 0.646 & 0.460 \\
\hline $\begin{array}{l}\text { Actual purchase } \\
\text { behavior(PB) }\end{array}$ & 0.800 & 0.800 & 0.500 & 0.158 \\
\hline $\begin{array}{l}\text { Post-purchase } \\
\text { behavior(PPB) }\end{array}$ & 0.833 & 0.830 & 0.502 & 0.101 \\
\hline
\end{tabular}

Table 3: Reliability and Validity of constructs

The value of composite reliability is coming above 0.7 , the values of Average Variance Extracted are coming above 0.5 and the values of MSV are smaller than the value of AVE. These figures clearly prove the convergent and discriminant validity within the construct.

\section{B. Measurement Model}

The model of measurement was checked by carrying out CFA in AMOS. The measure to check the model overall goodness fitwas Cmin/DF, CFI, NFI and RMSEA. The values depicted in Table 5 prove the measurement model to be a good fit as the $\mathrm{Cmin} / \mathrm{Df}=1.974$ and $\mathrm{p}$ value is 0.000 , the value lower than the threshold value of .5 [42]. Also, the value of CFI, TLI, ILI and NFI are coming out to be very close to 0.9 or above 0.9 as recommended by [16,31].It is quite evident from Table 4 that the value of RMSEA is below the recommended value of 0.1 [31, strongly proves that the data is well fitted to the model.

\begin{tabular}{|c|c|c|c|c|c|c|c|}
\hline$\chi \mathbf{2}$ & df & $\chi^{2} / \mathbf{d f}$ & $\begin{array}{c}\text { RM } \\
\text { SEA }\end{array}$ & NFI & CFI & TLI & GFI \\
\hline 1756.58 & 890 & 1.97 & 0.04 & 0.89 & 0.94 & 0.94 & 0.87 \\
\hline
\end{tabular}

\section{Table 4: Model Fit of Measurement Model}

\section{Structural Model}

After conducting CFA and confirming the measurement model was found to be a good fit, the structural model was developed using AMOS software (Figure 2). The hypothesis formulated for the proposed model was calculated through the support ofp - values. The p-values related to all thefactorsare depicted in Table 7 which clearly shows that the p-values are smaller than 0.001 of all the independent factors except Effort Expectancy and Social Influence. Thus, hypothesis supported are H1, H4, H5, H6, H7, H8,H9, H10 and rejecting $\mathrm{H} 2$ and $\mathrm{H} 3$. 


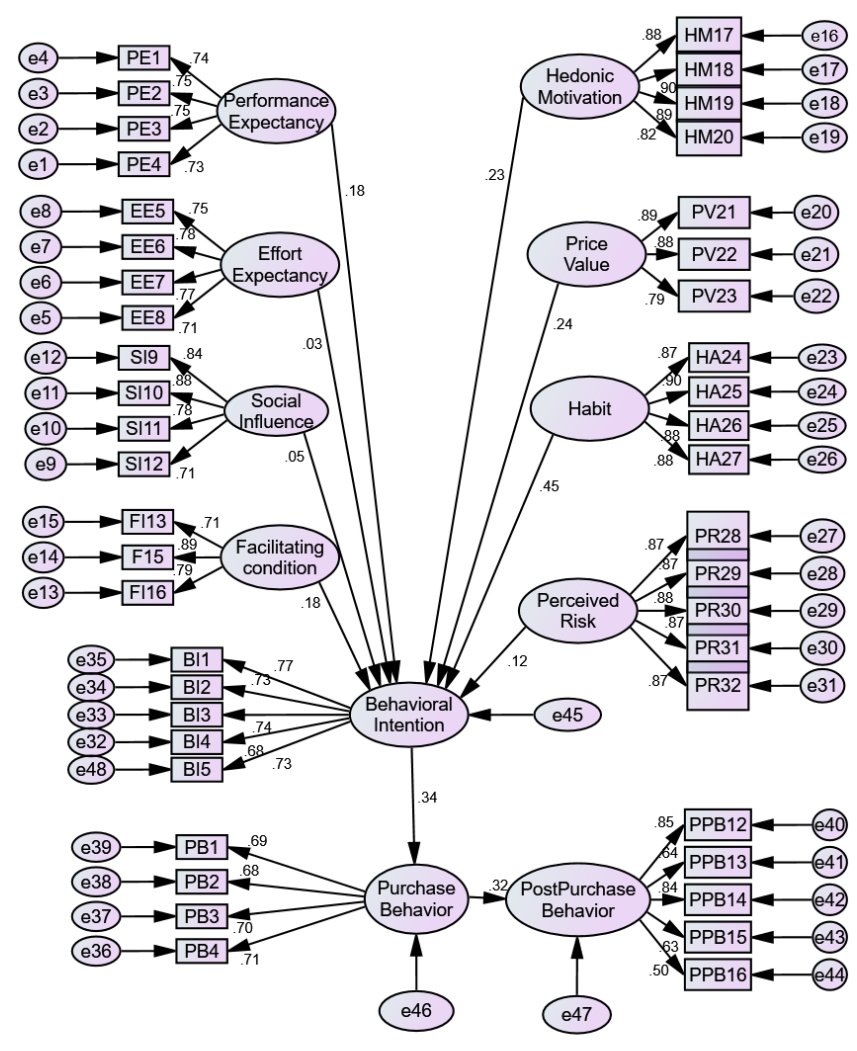

Figure-2: Structural Model with Path Estimates

\section{DISCUSSION AND CONCLUSION}

Habit was found to the most grounded indicator of adopting m-shopping fashion apps. The outcomes are in accordance with the past investigations [41] and in logical inconsistency to [27].

As individuals keep on utilizing the applications, this cultivates spontaneous utilization of the applications. Here conduct develops into Habit, and users unintentionally utilize m-style shopping applications. In agreement to past researches on mobile shopping [44]. Price value positively affect the formation of behavioural intention of young consumers to adopt mobile based fashion shopping apps and was also found to be the second highest predictor of behavioural intention to adopt m-shopping fashion apps. This can be reasoned as young consumers are more pricesensitive due to their limited pocket money. So, higher the benefits derived from the use of $\mathrm{m}$-shopping fashion app than the cost involved, higher will be the adoption rate. In concurrence with past research in mobile shopping [19]. The work findings discovered a strong association among hedonic motivation and BI of young consumers to adopt mobile based shopping via fashion apps. Therefore, it can be deduced that the app is enjoyable and fun because of their visual appeals and engaging pictures and drive to use m-shopping fashion app increases. Further, Facilitating Conditions significantly influence mobile users' behavioural intention. The results are in concurrence with previous research [2,41] and are inconsistent with [39]. The discoveries are not astonishing as most of the mobile apps are well furnished with frequently asked questions and provides good technical and customers support. Performance Expectancy was also found to affect behavioural intention of young consumers to adopt mobile based fashion shopping apps. This is as per prior outcomes of [8].This instigates the more individuals discover mobile based shopping using fashion apps advantageous as well as helpful, the more positive will be their intention to utilize these applications. However, the new construct, Perceived Risk(PR) manifested in UTAUT2 Model was found to be statistically significant to influence the formation of BI of young consumers to adopt the mobile based fashion shopping app. The reason for negative relation between perceived risk and adoption may be explained by following reasons. Since the majority of responders are young consumers are very concerned and not trusting towards providing the debit cards and credit cards information over internet, thus they prefer the COD option. The companies need to win trust of customers by explaining the steps taken for security of online transactions and other factors like easy return and privacy of information regarding transactions.

\section{IMPLICATIONS}

The research will be significant from the theoretical point of view as it is incorporating extended UATUT2 Model in the context of fashion application manifested with the new construct of perceived risk. Also, no scholarly research has extended model to find out the post-adoption. Also, this work will further validate extended UATUT2 Model in Indian Market. The proposed model related to $\mathrm{m}$-shopping fashion app has been suitably confirmed because of the high variance explained by the proposed model. In the Practical world, the findings of the research will help the managers, practitioners and fashion app developers in the mobile industry by providing with an improved idea about the determinants they need to consider while developing fashion mobile applications in order to come up with the applications which support consumers' needs and continued usage of their apps. This work will help the app developers get a better understanding of the preferences of their target audience and decrease failures. The results will be helpful to app developers, marketers, and overall fashion industry as a whole

\section{LIMITATIONS AND FUTURE SCOPE}

This work is not free from limitations and hence future studies could address the limitations. The results of this investigation are extracted on the basis of the responses of the young students belonging to the age group of (18-25). Thus, the results cannot be inferred to the general population and are restricted to the particular age group of young students. The future research should, therefore, focus on respondents belonging to different age groups and occupation in order to understand $\mathrm{m}$-shopping fashion app adoption. Furthermore, this research is based on cross sectional research design. Future work can consider the use of longitudinal longitudinal research design to understand the change in mobile app users' intention and behavior over a period of time. Also,future studies can do research on the different domain of mobile apps like games and food etc. to check if same barriers and drivers exist for them as well. 


\section{REFERENCES}

[1] A.Y.L. Chong, (2013a), "A two-staged SEM-neural network approach for understanding and predicting the determinants of m-commerce adoption", Expert Systems with Applications, Vol.40 No. 4, pp. 1240-1247.

[2] A.Y.L.Chong, (2013b), "Predicting m-commerce adoption determinants: a neural network approach", Expert Systems with Applications, Vol. 40 No. 2, pp. 523-530.

[3] C.C.Lewis, C.E. Fretwell, J.Ryan, \&J.B. Parham, (2013), "Faculty use of established and emerging technologies in higher education", A unified theory of acceptance and use of technology perspective, International Journal of Higher Education, Vol.2 No.2, pp.22-34.

[4] C.Fang and S. C. Fang. (2016), "Factors Affecting Consumer Stickiness to Continue Using Mobile Applications", International Journal of Mobile Communications, Vol.14 No.5, pp.431-453.

[5] C.Gan , and H. Li. 2018. "Understanding the Effects of Gratifications on the Continuance Intention to Use WeChat in China: A Perspective on Uses and Gratifications." Computers in Human Behavior, Vol.78, pp. 306-315.

[6] C.Kim,W.Li and Kim, D.J(2015)," An Empirical Analysis of Factors Influencing M-Shopping Use", International Journal of Human-Computer Interaction, Vol.31 No.12, pp:974-994.

[7] C.L.Goi, \& P.Y.Ng, (2011), "Perception of Young Consumers on Mobile Phone Applications in Malaysia" World Applied Sciences Journal", Vol.15 No. (1), pp. 47-55.

[8] C.Liao,P. Palvia \& H.N.Lin, (2006), "The roles of habit and web site quality in e-commerce", International Journal of Information Management, Vol. 26 No.6, pp. 469- 483

[9] C. M. Chiu, E. T.Wang, , H.Fang., and H. Y.Huang, (2014), "Understanding Customers' Repeat Purchase Intentions in B2C e-Commerce: The Roles of Utilitarian Value, HedonicValue and Perceived Risk." Information Systems Journal, Vol.24 No. 1, pp. 85-114.

[10] C.S Yu, (2012)," Factors affecting individuals to adopt mobile banking: empirical from the UTAUT model", Journal of Electronic Commerce Research, Vol.13 No. 2, pp.104-121.

[11] C. Wong, G. Tan, T. Hew and K. Ooi, (2016), "Can mobile TV be a new revolution in the television industry?", Computers in Human Behavior, Vol. 55, Part B, pp. 764-776.

[12] E.Moon, and T. Domina, (2015), "Willingness to use fashion mobile applications to purchase fashion products. A comparison between United States and South Korea", Journal of textile and Apparel, Technology and Management, Vol. 13, pp. 221-230.

[13] F.D.Davis, R.P. Bagozzi, and P.R. Warshaw, (1989), "User acceptance of computer technology: a comparison of two theoretical models", Management science, Vol. 35 No. 8, pp. 982-1003.

[14] G. Baptista, and T. Oliveira, (2015), "Understanding Mobile Banking:The Unified Theory of Acceptance and Use of Technology Combined with Cultural Moderators", Computers in Human Behavior, Vol.50, pp: 418-430.

[15] G.W.H. Tan, V. H. Lee, B. Lin, and K.B. Ooi,(2017), "Mobile applications in tourism: the Future of the tourism industry?", Industrial Management\& Data Systems, Vol. 117 No.3, pp.560-58.

[16] H.Baumgartner and C. Homburg, (1996), "Applications of structural equation modeling in marketing and consumer research: a review", International Journal of Research in Marketing, Vol. 13 No. 2,pp. 139-161.

[17] H.R.Marriott, M.D.Williams, (2018) "Enhancing the Customer Experience: Understanding UKConsumers' M-Shopping Adoption Intention” In: Krey N., Rossi P. (eds) BoundaryBlurred: A Seamless Customer Experience in Virtual and Real Spaces. AMSAC 2018.Developments in Marketing Science: Proceedings of the Academy of Marketing Science.Springer, Cham.

[18] H.Y. Wang, C. Liao and L.H. Yang, "What affects Mobile Application Use? The role of consumption values", International Journal of Marketing Studies, Vol.5 No. 2, pp. 11-22

[19] I. K.W. Lai, and G. Shi, (2015) "The Impact of Privacy Concerns on the Intention for Continued use of an Integrated Mobile Instant Messaging and Social Network Platform." International Journal of Mobile Communications, Vol. 13 No.6: pp.641 669.

[20] I.L.D. Harsono, M.L. A. Suryana, (2014)," Factors Affecting the Use Behavior of Social Media Using UTAUT 2 Model, Proceedings of the First Asia-Pacific Conference on GlobalBusiness, Economics, Finance and Social Sciences (AP14 Singapore Conference) Singapore, 1-3 August 2014 Paper ID: S471.

[21] J.H. Cheong, M.C.Park, and J.H. Hwang, (2004), "Mobile payment adoption in Korea: switching from credit card", in ITS 15th Biennial Conference, in Berlin, pp. 4-7.

[22] J.J.Hew,V.H. Lee, K.B. Ooi, andJ. Wei, (2015),"What catalyses mobile apps usage intention: an empirical analysis", Industrial Management \& Data Systems, Vol. 115 No. 7, pp. $1269-1291$.

[23] Jati. NugrohoJatmiko and Laksito. Herry.. 2012. AnalisisFaktor-faktor yang Mempengaruhi MinatPemanfaatandanPenggunaanSistem E-Learning. Diponegoro, Journal ofAccounting,Vol 1. No. 2.

[24] K. Lai, and D. C. Lai. (2014) "User Acceptance of Mobile Commerce: An Empirical study in Macau." International Journal of Systems Science, Vol. 45 No.6, pp: 1321-1331.

[25] K. Yang,(2012), "Consumer technology traits in determining mobile shopping adoption: An application of the extended theory of planned behaviour", Journal of Retailing and Consumer Services, Vol.19 No.5, pp: 484- 491.

[26] K.Madan and R. Yadav, (2016). (2016) "Behavioural intention to adopt mobile wallet: a developingcountry perspective", Journal of Indian Business Research, Vol. 8 No. 3, pp.227-244.

[27] K.Madan and R. Yadav, (2018) "Understanding and predicting antecedents of mobile shopping adoption: A developing country perspective", Asia Pacific Journal of Marketingand Logistics, Vol.30 No. 1, pp.139-162.

[28] L. Jia, D.Hall, and S.Sun,2014. "The Effect of Technology Usage Habits on Consumers'Intention to Continue Use Mobile Payments." Proceedings of Twentieth Americas

[29] L.Gao, K. A. Waechter, and X. Bai. 2015. "Understanding Consumers' Continuance Intention Towards Mobile Purchase: A Theoretical Framework and Empirical study - A Case of China." Computers in Human Behavior, Vol.53, pp.249-262.

[30] L.Morris, (2016). Which mobile fashion retail app has the best UX? Availableat:https://www.clickz.com/2015/11/06/which-mobile-fashio n-retail-app-has-the best-ux[Accessed 5April 2019].

[31] Localytics (2011, January)," First impressions matter! 26\% of apps downloaded in 2010 wereused just once" available at http://www.localytics.com/blog/2011/first-impressions-matter-26-per centof-apps-downloaded-used-just-once/(accessed on 10 April, 2019)

[32] L.T., Hu and P.M. Bentler,(1999), "Cut off criteria for fit indexes in covariance structure analysis: conventional criteria versus new alternatives", Structural Equation Modeling: A Multidisciplinary Journal, Vol. 6 No. 1, pp. 1-55.

[33] M Arcand., D. Pauzé (2017) Winning Over Customers with Mobile: A Fashion Industry Case Work. In: Rossi P. (eds) Marketing at the Confluence between Entertainment and Analytics. Developments in Marketing Science: Proceedings of the Academy of Marketing Science.Springer, Cham.

[34] M. Hasan, R. Kouser, S.S Abbas and M. Azeem, (2014)," Consumers Attitudes and Intentions to adopt Smartphone Apps: Case of Business Students", Pakistan Journal of Commerce andSocial Sciences, Vol.8 No. 3, pp. 763-779.

[35] M. Limayem, S. G. Hirt, and C. M. Cheung, (2007). "How HabitLimits the Predictive Powerof Intention", The Case of InformationSystems Continuance.” MIS Quarterly Vol. 31, pp.705-737.

[36] M.Groß, (2015). Exploring the acceptance of technology for mobile shopping: An empirical investigation among smartphone users",International Review of Retail Distribution \& Consumer Research, Vol.25 No.3, pp.215-235.

[37] M.R., Islam, and T.A.Mazumder, (2010), "Mobile application and its global impact", International Journal of Engineering \& Technology, Vol. 10 No. 6, pp. 72-78.

[38] P. Hanafizadeh, M. Behboudi, A.A.Koshksaray, and M.J.S. Tabar (2014), Mobile-bankingadoption by Iranian bank clients", Telematics and Informatics, Vol. 31 No. 1, pp. 62-78.

[39] P.K.Chopdar, N.Korfiatis, V.J Sivakumar, and M.D Lytras, (2018) "Mobile Shopping Apps Adoption and Perceived N. Risks: A Cross-Country Perspective Utilizing the Unified Theory ofAcceptance and Use of Technology." Computers in Human Behavior, Vol.86, pp.109-128.

[40] Peter, M.J,Ryan, (1976)," An investigation of perceived risk at the brand level", "Journal of Marketing Research, Vol.2 No.13, pp.184-188.

[41] Preeti Tak and S.Panwar, (2017) "Using UTAUT 2 model to predict mobile app-based shopping: evidences from India", Journal of Indian Business Research, Vol. 9 No. 3, pp. 248-264.

[42] R.E., Schumacker and R.G.Lomax,(2004), A Beginner's Guide to Structural Equation Modelling,Erlbaum, Mahwah, NJ.

[43] R.H. Tsiotsou \&J. Wirtz, (2015), "The Three-Stage Model of Service Consumption," in: The Handbook of Service Business: Management, Marketing, Innovation and Internationalisation, by 
Bryson, J. R. and Daniels, P. W. (eds.) Cheltenham: Edward Elgar, United Kingdom, 105-128

[44] S. Yang, Y. Chen, and J. Wei. (2015) "Understanding Consumers' Web-Mobile Shopping Extension Behavior: A Trust Transfer Perspective." Journal of Computer Information Systems, Vol.55 No.2, pp:78-87.

[45] S.C.Kim, D.Yoon,\& E.K. Han,(2016), “Antecedents of mobile app usage amongsmartphone users", Journal of Marketing Communications, Vol.22 No.6, pp.653-670.

[46] S.Hong, J.Y.Thong, and K.Y.Tam,(2006) "Understanding Continued InformationTechnology Usage Behavior: A Comparison of Three Models in the Context of Mobile Internet." Decision Support Systems, Vol.42 No.3, pp. 1819-1834.

[47] S.Pahnila,S.Mikkoand X.,Zheng(2011). "Integrating Habit intoUTAUT: The Chinese eBay Case",Pacific Asia Journal of the Association for Information System, Vol. 3 No. 2pp 1-30

[48] Statista.com. (2015). Retail m-commerce sales in India from 2015-2020 |Statistic. [online] Available at: https://www.statista.com/statistics/266119/india-retail- mcommercesales//[Accessed 10 April. 2019].

[49] T.T.T. Phamand J.C, Ho, J.C. (2014), "What are the core drivers in consumer adoption of NFC- based mobile payments? A proposed research framework", Management of Engineering \&Technology (PICMET), 2014 Portland International Conference, Kanazawa, pp.3041-3049.

[50] T.Y.Chang, C.J. Tsai, and J.H. Lin, (2012), “A graphical-based password keystroke Dynamic authentication system for touch screen handheld mobile devices", The Journal of Systems and Software", Vol. 85 No. 5, pp. 1157-1165.

[51] T., Zhou, (2013), "Understanding Continuance Usage of Mobile Sites.” Journal of IndustrialManagement \& Data Systems, Vol.113 No. 9, pp.1286-1299.

[52] Uravshi Tandon., R. Kiran and A.N. Sah. (2016), "Understanding online shopping adoption in India: unified theory of acceptance and use of technology 2 (UTAUT2) with perceived risk application" Service Science, Vol.8 No. 4, pp. 420-437.

[53] V. Venkatesh, J.Y. Thong \&X. Xu, (2012). Consumer acceptance and use of information technology: extending the unified theory of acceptance and use of technology. MIS quarterly, 36(1), 157-178.

\section{AUTHORS PROFILE}

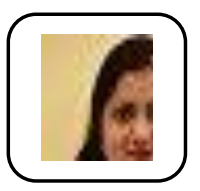

Dr Sunayna Khurana has done $\mathrm{PhD}$ in Service Marketing, MBA in Marketing, UGC NET qualified, currently working asProfessor \&HOD, MBA at Chandigarh Business School of Administration. She deals in Service Marketing, Consumer Behavior, Advertising and Sales management, Retail Management, Marketing Research. She is a recipient of National Award of Best Professor in Marketing in 11th DNA Innovative Education Leadership Awards in 2019. She has more than 12 years' experience in academics and 3 years' experience in corporate sector. She is also guiding $8 \mathrm{PhD}$ scholars under IKGPTU out of which one student also awarded the PhD degree. She has written 40 research papers for various established International \& National Journals.

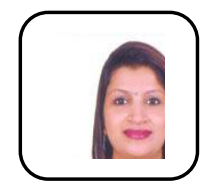

Dipti Jain has completed her post-graduation and is pursuing PhD from I.K. Gujral Punjab Technical University,Jalandhar and is UGC NET qualified. Her areas of interest include research in consumer behavior, m-commerce. She had published research papers in various National and International journals of repute and has presented papers in conference. 